\title{
ANALISIS PEMECAHAN MASALAH KEMAMPUAN MENULIS MAHASISWA MELALUI MEDIA PEMBELAJARAN BERBASIS VIDEO
}

\author{
Dahlia Sirait ${ }^{1}$ \\ Aminda Tri Handayani ${ }^{2}$ \\ Universitas Muslim Nusantara Alwashliyah ${ }^{1,2}$ \\ dahliasirait25@gmail.com
}

\begin{abstract}
Abstrak
Penelitian ini bertujuan untuk mengetahui pemecahan masalah kemampuan menulis mahasiswa dan mengetahui apa media pembelajaran dengan berbasis video dapat memecahkan masalah kemampuan menulis mahasiswa.Penelitian ini menggunakan metode deskriptif kualitatif, yang bertujuan untuk mengumpulkan data siswa agar dapat mengetahui permasalahan siswa dan kemampuan mereka dalam menulis berbasis video.Populasi dalam penelitian ini adalah seluruh mahasiswa semester tujuh jurusan Pendidikan Bahasa Inggris UMN Al Washliyah sebanyak 30 orang. Data yang digunakan dalam penelitian ini adalah data berbentuk observasi, wawancara langsung dan memberikan test kepada siswa. Instrument yang digunakan dalam pengumpulan data yaitu test tulisan leksikal. Penelitian ini dilakukan melalui tiga tahap yaitu tahap pertama adalah mengumpulkan data dari observasi, wawancara dan test, tahap kedua yaitu mengklasifikasikan data dan tahap ketiga adalah menganalisis data yang ada dan juga menyimpulkan.Berdasarkan hasil pengolahan data diperoleh bahwa hasil lembar observasi tersebut dapat dikatakan penerapan media pembelajaran pada kemampuan menulis berhasil dapat memecahkan masalah dengan hasil 10\% siswa di dalam kelas mendapatkan kriteria baik dan 90 \% siswa lainnya mendapat kriteria Sangat Baik. Dan dari wawancara bahwa mereka terbantu dengan adanya video dan manambah vocabulary yang ada dan mereka lebih aktif didalam kelas dengan adanya tampilan video pada proses pembelajaran.Menulis kalimat bahasa Inggris dengan menggunakan video pada mahasiswa Pendidikan Bahasa Inggris UMN Aw mengalami peningkatan baik dengan nilai sebesar 86,17. Selain itu dengan bantuan video terdapat motivasi dari dosen untuk mempengaruhi nilai belajar mahasiswa.
\end{abstract}

Keywords: pemecahan masalah, kemampuan, menulis, video

\begin{abstract}
This study aims to determine the problem solving of students' writing abilities and to find out what learning media with video-based can solve the problem of students' writing abilities. This study uses descriptive qualitative methods, which aim to collect student data in order to find out students' problems and their abilities in writing based on video The population in this study were all seventh semester students majoring in English Education at Al Washliyah UMN as many as 30 people. The data used in this study were data in the form of observation, direct interviews and giving tests to students. The instrument used in data collection is the lexical writing test. This research was carried out through three stages, namely the first stage was collecting data from observations, interviews and tests, the second stage was classifying data and the third stage was analyzing existing data and also concluding. Learning on the ability to write successfully can solve problems with the results of $10 \%$ of students in the class getting good criteria and $90 \%$ of other students getting Very Good criteria. And from the interview that they were helped by the existing videos and vocabulary enhancements and they were more active in the classroom with a video display in the learning process. Writing English sentences by using videos on UMN Aw English Education students experienced a good increase with a value of 86.17. In addition, with the help of video there is motivation from lecturers to influence student learning values.
\end{abstract}


Keywords: problem solving, ability, writing, video

\section{PENDAHULUAN}

Berkembangnya teknologi pendidikan atau IT membuat bahasa inggris menjadi lebih dinamis dalam empat keahlian dalam bahasa inggris misalnya membaca, berbicara, mendengar dan menulis. Sehingga mahasiswa diharapkan dapat menganalisis atau mengembangkan empat keahlian menjadi lebih baik. Dalam bahasa inggris menulis merupakan bagian terpenting dalam menyalurkan berbagai ide dalam sebuah tulisan. Akan tetapi sebagian besar mahasiswa sangat kurang dalam mengembangkan tulisan karena kurangnya beberapa ide atau kosa kata untuk membentuk sebuah kalimat, sehingga membuat mahasiswa mengalami kesulitan dalam menulis teks, tulisan ilmiah maupun narative karena kurangnya ide dalam membentuk kalimat.

Pada zaman Milenial dalam mengatasi berbagai macam permasalahan yang dihadapi mahasiswa terbentuk berbagai macam permasalahan yang sangat identik dalam berbagai problema dalam menghadapi era teknologi yang mengharuskan mahasiswa harus lebih update dalam mengembangkan ide dalam sebuah bacaan atau tulisan yang akan dikembangkan di media sosial ataupun tulisan ilmiah. Sehingga mereka tidak dengan mudah dalam menulis antara kalimat yang kekurangan ide dengan kalimat ilmiah atau berita yang dapat dipercaya dan tidak sekedar menulis dengan berbagai berita yang hoax.

Mengatasi berbagai macam permasalahan siswa dalam menulis membuat peneliti mengembangkan berbagai macam media pembelajaran terhadap mahasiswa dalam menulis. Akan tetapi peneliti disini menggunakan media pembelajaran berbasi video sebagai alat audio visual yang merangsang kemampuan menulis siswa dan menganalisis dapat mengatasi permasalahan yang dihadapi mahasiswa dalam kemampuan menulis.

\subsection{Rumusan Masalah}

ini adalah:

Rumusan masalah dalam penelitian

1. Bagaimana mengetahui pemecahan masalah kemampuan menulis mahasiswa melalui media pembelajaran?

2. Apakah media pembelajaran dengan berbasis video dapat memecahkan masalah kemampuan menulis mahasiswa?

\subsection{Tujuan Khusus}

Tujuan khusus penelitian ini sebagai berikut:

1. Mengetahui kemampuan siswa dalam pemecahan masalah kemampuan menulis mahasiswa melalui media pembelajaran

2. Memperbaiki kemampuan menulis dengan media pembelajaran dengan berbasis video dapat memecahkan masalah.

\section{METODE}

\subsection{Desain Penelitian}

Penelitian ini didasarkan pada metode deskriptif kualitatif, yang bertujuan untuk mengumpulkan data siswa agar dapat mengetahui analisis pemecahan masalah kemampuan menulis mahasiswa melalui media pembelajaran berbasis video. Sehingga kita dapat melihat kemampuan mahasiswanya.Penelitian deskriptif kualitatif adalah penelitian yang digunakan untuk memberikan suatu fenomena atau penggambaran kondisi apa yang bisa tanpa manipulasi terhadap salah satu variabel. mengatakan, "Deskriptif kualitatif menggambarkan sesuatu dan menganalisis kondisi yang ada". 
Metode penelitian yang digunakan dalam kajian ini adalah metode deskriptifanalitis dengan pendekatan kualitatif, dimana data tersebut berwujud kata - kata dan bukan rangkaian angka yang telah dikumpulakn dan diproses berdasarkan analisis.

\subsection{Lokasi Penelitian}

Lokasi penelitian dilakukan di Universitas Muslim Nusantara Al Washliyah J1. Garu II No. 02, Medan.

\subsection{Populasi dan Sampel}

\section{Populasi}

Populasi adalah keseluruhan objek penelitian sebagai sumber data yang memiliki karakteristik didalam suatu penelitian. Populasi dalam penelitian ini adalah mahasiswa pendidikan bahasa inggris semester 7 yang berjumlah 30 siswa.

2. Sampel

Sampel adalah pemilihan wakil dari seluruh objek penelitian. Berdasarkan populasi yang ada, peneliti mengambil 30 siswa secara acak sebagai penelitian populasi.

\subsection{Instrumen Penelitian}

Test ini menggunakan video dalam bentuk rubrik test tulisan dan rubrik pengamatan (non test) untuk membuatnya sesuai dengan tujuannya; Uji reliabilitas test akan dipertahankan dengan mencobanya. Penulis akan meminta siswa menulis kalimat bahasa inggris dengan menggunakan video.

\subsection{Teknik Mengumpulkan Data dan} Analisis Data

Untuk mengumpulkan data penelitian ini dilakukan sejak saat mengidentifikasi masalah, saat observasi dalam kelas dengan pengisian lembar observasi yang dilakukan peneliti, dan mengumpulakan hasil kerja mahasiswa untuk dihitung tingkat perbaikannya. Selain itu wawancara juga dilakukan kepada beberapa mahasiswa untuk mengetahui hasil dari media yang dipakai untuk perbaikan hasil belajar, hasil penilaiannya berupa rubric penilaian.

Menganalisis data menurut, peneliti akan menggunakan langkah-langkah sebagai berikut:

1. Mengumpulakan tugas - tugas mahasiswa yang menulis kalimat bahasa inggris dengan media video.

2. Mereduksi data - data menulis kalimat bahasa inggris.

3. Penyajian data yaitu menganalisis dan mendeskripsikan tulisan - tulisan kalimat bahasa inggris.

4. Penarikan kesimpulan dilakukan dari pengumpulan data- data dari permasalahan yang ada.

\subsection{Tahap- Tahap Penelitian}

Adapun tahap - tahap yang dilaksanakan sebagai berikut:

1. Tahap persiapan. Dalam tahap persiapan penelitian ini, kegiatan yang dilakukan oleh ketua pengusul dan anggota pengusul adalah membaca dan mengumpulkan data dari mahasiswa.

2. Tahap pelaksanaan. Dalam tahap ini, ketua dan anggota pengusul menyiapkan instrument dari rubrik tulisan dan lembar observasi.

3. Tahap observasi. observasi terhadap data ini dilakukan dengan tujuan agar memperoleh informasi dari mahasiswa.

4. Tahap refleksi. Dalam tahap refleksi yang dilakukan ketua dan anggota pengusul adalah menganalisis data data dari tulisan yang dibuat oleh mahasiswa.

\section{HASIL DAN PEMBAHASAN}

\subsection{Hasil}

Pada bagian ini dibahas hasil penelitian Pemecahan Masalah Kemampuan Menulis Mahasiswa Melalui Media Pembelajaran Berbasis Video. Penyajian berikut disajikan dengan analisis kualitatif. Penyajian data kualitatif memaparkan data proses pembelajaran 
menulis kalimat bahasa inggris dengan menggunakan media pembelajaran pada mahasiswa. Sedangkan data presentasi melihat kemampuan siswa dalam memperbaiki menulis kalimat bahasa inggris dengan berbasis video.

\subsection{Pedoman Observasi}

Pedoman observasi dalam penelitian ini diperoleh dari hasil pengamatan selama melakukan penelitian di mana peneliti ikut serta langsung di lapangan melakukan pengamatan dan diperoleh hasil data sebagai berikut :

Pada kelas pendidikan bahasa inggris semester tujuh, ditemukan kemampuan menulis mahasiswa melalui media pembelajaran meliputi:

$\frac{3}{30} \times 100 \%=10 \%$ Siswa dengan kriteria Baik

$\frac{27}{30} \times 100 \%=90 \%$ Siswa dengan kriteria Sangat Baik

Jadi dari hasil lembar observasi tersebut dapat dikatakan penerapan media pembelajaran pada kemampuan menulis berhasil dapat memecahkan masalah dengan hasil $10 \%$ siswa di dalam kelas mendapatkan kriteria baik dan $90 \%$ siswa lainnya mendapat kriteria Sangat Baik.

Dari data tersebut pada kelas tersebut dapat dikatakan pemecahan masalah siswa melalui media pembelajaran lebih aktif dibandingkan dengan siswa pada kelas yang tidak menerapkanya media pembelajaran.

\subsection{Wawancara}

Wawancara dilakukan dengan beberapa siswa semester tujuh, peneliti mengajukan beberapa pertanyaan seputar proses pembelajaran dengan menerapkan media pembelajaran video dalam menulis kalimat bahasa inggris. Adapun isi wawancaranya meliputi:

Peneliti : Bagaimana pendapat kamu tentang media pembelajaran dengan video?
Siswa 1 : Menurut saya Bu sangat menarik karena dapat membantu kosa kata saya dan saya lebih aktif dalam menulis.

Peneliti : Apakah media video dapat mengatasi masalah menulis kamu?

Siswa 2 : Iya $\mathrm{Bu}$, saya terbantu dengan adanya media video dan saya dapat menulis dengan baik.

Peneliti : Apakah kamu lebih aktif dalam menulis kalimat bahasa inggris dengan menggunakan video?

Siswa 3 : Iya bu, saya lebih aktif dan lebih menguasai vocabulary yang banyak karena adanya video.

Peneliti : Bagaimana media pembelajaran yang baik menurut kamu?

Siswa 4 : Menurut saya bu, media pembelajaran berbasis video yang baik menurut saya karena menambah pemahaman saya dan tidak membosankan.

Proses melakukan wawancara siswa memberikan pernyataan bahwa mereka terbantu dengan adanya video dan manambah vocabulary yang ada dan mereka lebih aktif didalam mdkrkelas dengan adanya tampilan video pada proses pembelajaran. Dan didalam kelas lebih aktif dalam proses belajar dan mereka juga sangat antusias dalam menulis kalimat bahasa inggris sehingga pemecahan masalah teratasin dengan adanya video.

\subsection{Media Video}

Video yang digunakan dalam penulisan bahasa inggirs adalah video yang menggunakan aplikasi Video scribe. Aplikasi ini dipilih karena menampilkan animasi-animasi menarik yang dapat menarik rasa ingin tahu untuk melihat tayangan yang ditampilkan. Dan dapat 
merangsang kemampuan menulis bahasa inggris yang baik.

\subsection{Pembahasan}

\subsubsection{Pemecahan Masalah Kemampuan Menulis Mahasiswa melalui Media Pembelajaran}

Setelah melakukan observasi yang dilaksanakan oleh peneliti ditemukan bahwa Jadi dari hasil lembar observasi tersebut dapat dikatakan penerapan media pembelajaran pada kemampuan menulis berhasil dapat memecahkan masalah dengan hasil $10 \%$ siswa di dalam kelas mendapatkan kriteria baik dan $90 \%$ siswa lainnya mendapat kriteria Sangat Baik.

Dari data tersebut pada kelas tersebut dapat dikatakan pemecahan masalah siswa melalui media pembelajaran lebih aktif dibandingkan dengan mahasiswa pada kelas yang tidak menerapkanya media pembelajaran. Dan proses wawancara mahasiswa memberikan pernyataan bahwa mereka terbantu dengan adanya video dan manambah vocabulary yang ada dan mereka lebih aktif didalam kelas dengan adanya tampilan video pada proses pembelajaran. Dan didalam kelas lebih aktif dalam proses belajar dan mereka juga sangat antusias dalam menulis kalimat bahasa inggris sehingga pemecahan masalah teratasin dengan adanya video. Oleh karena itu pemecahan masalah kemampuan menulis mahasiswa melalui media pembelajaran dapat teratasin dengan baik.

\subsubsection{Media Pembelajaran dengan} Berbasis Video dapat Memecahkan Masalah Kemampuan Menulis Mahasiswa

Berdasarkan hasil test tertulis dalam kemampuan menulis kalimat bahasa inggris media pembelajaran dengan berbasis video dapat memecahkan masalah, yaitu dilihat dari skor yang didapat oleh mahasiswa dengan rata - rata nilai yang sangat baik dan baik dalam test tertulis yang diberikan oleh peneliti. Sehingga dengan media pembelajaran berbasis vide yaitu video scribed yang berbemtuk animasi terbantu menyelesaikan masalah siswa dalam menulis kalimat bahasa inggris. Dan mahasiswa dapat memiliki rasa ingin tahu untuk melihat tampilan yang diberikan dan mencoba menuliskan dalam kalimat bahasa inggris.

Table 5.1 Skor Kemampuan Menulis Kalimat Bahasa Inggris dengan Menggunakan Video

\begin{tabular}{|c|c|c|c|}
\hline No. & Nama / Inisial & Skor & Keterangan \\
\hline 1 & Rahmah & 90 & Sangat Baik \\
\hline 2 & Ayu & 85 & Baik \\
\hline 3 & Rizky & 85 & Baik \\
\hline 4 & Masitha & 85 & Baik \\
\hline 5 & Liza & 90 & Sangat Baik \\
\hline 6 & Shintya & 85 & Baik \\
\hline 7 & Lorry & 90 & Sangat Baik \\
\hline 8 & Nurcantika & 90 & Sangat Baik \\
\hline 9 & Purnama & 85 & Baik \\
\hline 10 & Khalila & 80 & Baik \\
\hline 11 & Nadya & 80 & Baik \\
\hline 12 & Kirani & 90 & Sangat Baik \\
\hline 13 & Nadya & 90 & Sangat Baik \\
\hline 14 & Livia & 80 & Baik \\
\hline 15 & Anissa & 90 & Sangat Baik \\
\hline 16 & Khairinda & 90 & Sangat Baik \\
\hline 17 & Nana & 85 & Baik \\
\hline 18 & Naomy & 95 & Sangat Baik \\
\hline 19 & Indah & 90 & Sangat Baik \\
\hline 20 & Karina & 90 & Sangat Baik \\
\hline 21 & Rossa & 80 & Baik \\
\hline
\end{tabular}




\begin{tabular}{|l|l|c|c|}
\hline 22 & Doni & 80 & Baik \\
\hline 23 & Jenny & 90 & Sangat Baik \\
\hline 24 & Naomi & 80 & Baik \\
\hline 25 & Faniyyah & 85 & Baik \\
\hline 26 & Aprissa & 80 & Baik \\
\hline 27 & Kennyah & 90 & Baik \\
\hline 28 & Sandy & 85 & Baik \\
\hline 29 & Nayla & 80 & Sangat Baik \\
\hline 30 & Licci Ditta & 90 & Baik \\
\hline & Total & $\mathbf{8 6 , 1 7}$ & \\
\hline
\end{tabular}

Berdasrkan tabel 5.2 tentang skor kemampuan menulis kalimat bahasa Inggris dengan menggunakan video dapat teratasi dengan baik dan sangat baik setiap mahasiswa dengan skor nilai rata - rata yaitu 86,17 yang bernilai baik dan meningkat untuk setiap mahassiswa setelah menggunakan video scribed yaitu video animasi. Dan dapat dinyatakan bahwasannya menulis kalimat bahasa Inggris dengan menggunakan video pada mahasiswa Pendidikan Bahasa Inggris UMN Aw mengalami peningkatan baik selain dengan bantuan video, terdapat motivasi dari dosen untuk mempengaruhi nilai belajar mahasiswa.

\section{KESIMPULAN}

Berdasarkan hasil penelitian dan pembahasan, maka dapat kesimpulan dari penelitian ini adalah:

1. Data observasi yang dilaksanakan oleh peneliti ditemukan bahwa Jadi dari hasil lembar observasi tersebut dapat dikatakan penerapan media pembelajaran pada kemampuan menulis berhasil dapat memecahkan masalah dengan hasil $10 \%$ siswa di dalam kelas mendapatkan kriteria baik dan $90 \%$ siswa lainnya mendapat kriteria Sangat Baik. Dan dari wawancara bahwa mereka terbantu dengan adanya video dan manambah vocabulary yang ada dan mereka lebih aktif didalam kelas dengan adanya tampilan video pada proses pembelajaran.

2. Menulis kalimat bahasa Inggris dengan menggunakan video pada mahasiswa Pendidikan Bahasa Inggris UMN Aw mengalami peningkatan baik dengan nilai sebesar 86,17, selain itu dengan bantuan video terdapat motivasi dari dosen untuk mempengaruhi nilai belajar mahasiswa.

\section{DAFTAR PUSTAKA}

Arsyad, Azhar. (1997). Media Pembelajaran. Jakarta: PT: Raja Grafindo Persada.

Bogdan, R.C., Biklen, S.K. (1982). Qualitative Research for Education: an introduction to theory and method. Boston: Allyn and Bacon. Inc

Dahlia Sirait \& Yulia Sari Harahap. Menulis Kalimat Bahasa Inggris Menggunakan Reality Media pada Mahasiswa Jurusan Psikologi Universitas Medan Area. (2018). Medan: Jurnal Penelitian Pendidikan Bahasa dan Sastra (JP2BS) 4(1): 453

E Wilson, et al (2011). Modelling the development of written language. Reading and writing 24, 203 - 220.

Gagne, R. M \& Driscoll, M.P. (2007). Essential of Learning for Instruction. New Jersey

Harmer, Jeremy. (2002). The Practice of English Language Teaching. New York: Longman

Hidayat, Asep Ahmad. (2006). Filsafat Bahasa Mengungkap Hakikat Bahasa, 
Makna dan Tujuan. Bandung: Remaja Rosda Karya.

Harmer, Jeremy. (2004). How to Teach Writing. Cambridge: Longman.

Harmer, Jeremy. (2007). The Practice of English Language Teaching.(4th Edition). Cambridge: Longman.

Novia Nur Ikhlasia. (2013). Menggunakan Penulisan Kooperatif dan Video untuk Meningkatkan Keterampilan Menulis Siswa pada Teks Deskripsi Kelassiswa $7 c$ di SMP IT Abu Bakar Yogyakarta Ditahun Akademik 2012/2013. Yogyakarta: UNY

Suardiman, Siti Partini et.al. 2008. Perkembangan Peserta Didik. Yogyakarta: UNY

Yeni Alfiani. (2017). Keefektifan pembelajaran menulis teks berita menggunakan model problem based learning dan model experiential learning dengan media video pada siswa kelas VIII SMP/MTS. Semarang. UNES 